\title{
Fermented Japanese snail fertilizer reduces vapor pressure deficit that improves indigenous corn growth (Zea mays var. Tiniguib)
}

\author{
Nonna Fatima H. Abello1*, Edivine A. Remedios ${ }^{2}$, Danny E. Carabio², Valerie U. Pascual ${ }^{3}$, Pet Roey L. Pascual ${ }^{1,2}$ \\ ${ }^{1}$ Crop Biotechnology Unit, Center for Studies in Biotechnology, Cebu Technological University, Barili Campus, Barili, Cebu, Philippines \\ ${ }^{2}$ Crop Science Department, College of Agriculture, Cebu Technological University, Barili Campus, Barili, Cebu, Philippines \\ ${ }^{3}$ Department of Agricultural Economics and Development Studies, Cebu Technological University, Barili Campus, Barili, Cebu, Philippines
}

Received:

March 11, 2021

Accepted:

May 26, 2021

Online First:

June 08, 2021

Published:

September 21, 2021

Correspong author email:

nonnafatima.abello@ctu.edu.p

\begin{abstract}
In the Philippines, native corn acts as a rice substitute during rice scarcity, making it the second most important staple crop. Japanese snail is considered an economically important mollusk pest but is known to address plant growth problems when used as amino acid fertilizer. The study compared seaweed residue, bamboo shoot residue, Japanese snail residue and their combination with organic pesticide, Guduchi, to commercially available compost fertilizer (10t/ha). These were done in three replications arranged in Randomized Complete Block Design. Photosynthetic parameters were measured using LI-6800 Portable Photosynthesis System. Application of Japanese snail residue improved height from 4th to 8th week by $67.53 \mathrm{~cm}$. Bamboo shoot residue also showed effectiveness in improving the plant height on the 8 th week at $139.13 \pm 6.28 \mathrm{SD} \mathrm{cm}$. On leaf length, Japanese snail residue outperformed the commercial basal organic fertilizer from the second up to the eighth week by $38.5 \mathrm{~cm}$. On reproductive stage, Japanese snail showed the highest weight of ears at 86.6 $20.36 \mathrm{SD} g$ and is comparable with seaweed residue in the weight of kernels per ear at $69.60 \pm 1.48 \mathrm{SD}$ g. However, in the computed yield, Japanese snail fertilizer has the lowest at 2.13 $\pm 09 \mathrm{SD} g$ but the combination of pesticide and Japanese snail obtained the highest at $3.33 \pm 04 \mathrm{SD}$ g. Seaweed residue alone attained the highest transpiration rate and the lowest assimilation rate at $1604168655.67 \pm 191.66 \mathrm{SD} \mu \mathrm{mol} \mathrm{H} 2 \mathrm{O} \mathrm{m}-2 \mathrm{~s}-1$ and $13.16 \pm 0.69 \mathrm{SD} \mu \mathrm{mol}$ $\mathrm{CO} 2 \mathrm{~m}-2 \mathrm{~s}-1$, respectively while the combination of Japanese snail and Guduchi was the one that improved stomatal conductance to $\mathrm{CO} 2$ and the total conductance to $\mathrm{CO} 2$ at $478.6350 \pm 34.82 \mathrm{SD} \mu \mathrm{mol} \mathrm{mol}^{-}$and $47.5083 \pm 3.55 \mathrm{SD} \mathrm{Pa}$. Japanese snail residue has the lowest vapor pressure deficit at leaf temperature at $4.54 \pm 0.02 \mathrm{SD} \mathrm{kPa}$ which showed significantly strong correlation with increase leaf length and plant height. Hence, Japanese snail residue fertilizer has the potential to be used as solid organic fertilizer for the growth of indigenous corn.
\end{abstract}

Keywords: Organic agriculture, Japanese snail, Seaweed residue, Morphological responses, Photosynthetic responses

\section{How to cite this:}

Abello NFH, Remedios EA, Carabio DE, U. Pascual VU and Pascual PRL, 2021. Fermented Japanese snail fertilizer reduced vapor pressure deficit which improves indigenous corn growth (Zea mays var. Tiniguib). Asian J. Agric. Biol. 2021(4): 202102087. DOI: https://doi.org/10.35495/ajab.2021.02.087

This is an Open Access article distributed under the terms of the Creative Commons Attribution 3.0 License. (https://creativecommons.org/licenses/by/3.0), which permits unrestricted use, distribution, and reproduction in any medium, provided the original work is properly cited. 


\section{Introduction}

Maize is one of the most known and powerful cereals crops, which is popularly used for food, fodder and also for medical purpose in the world. More than 3,500 uses of corn products were enumerated (Huma et al., 2019). It is reported to have a good source of vitamins A, B, E and many minerals. In Central Visayas, Cebu has the biggest area planted to corn (55.2\% of total area) (BAS, 2012) and is considered a top corn producer in 2018, contributing $54.63 \%$ in the total corn production in the entire region (Amper et al., 2018).

Farmers used high amount of chemicals for fertilizer, pesticide, herbicide and fungicide because of their desperation for increased yield but this greatly have negative effects to the environment which may compensate the future of agriculture.

Organic fertilizers are able to build the ability of soil to absorb water, increase resistance to erosion and improve biodiversity. This is well known to be very effective in improving plant growth (Pascual et al., 2020). These have a broad range of nutrients and are helpful in maintaining the soil health. These will improve the soil carbon status and soil quality which helps in improving, carbon sequestration. It flourishes the rhizosphere micro-flora by providing nutrients that stimulate growth of plants (Lesik et al., 2019).

Japanese snails are highly polyphagous, damaging more than 500 plant species including fruit crops, vegetables, ornamental plants and field crops. Their shell has a chemical composition which includes proteins, carbohydrates, fats, and minerals such as iron, zinc, copper (Jatto et al., 2010). Its conspicuous occurrence is noticed during rainy season. The climatic conditions like high humidity $(>80 \%)$ and moderate temperature $\left(9-29^{\circ} \mathrm{C}\right)$ are more congenial for the population build-up of the pest (Sreenivasa et al., 2016). Golden Apple Snail residue significantly improved soil $\mathrm{pH}$, contents of total organic carbon (TOC), total nitrogen (TN), total phosphorus (TP), and available nitrogen but decreased soil available phosphorus (AP) content due to phosphorus sorption induced by soil organic matter (OM) and high $\mathrm{pH}$ (Wang et at., 2020).

High vapor pressure deficit typically causes plants to close their stomata to minimize water loss and avoid critical water tension within the xylem, which occurs at the cost of reduced photosynthesis. In vapor pressure deficit, stomata get smaller as these increases which means carbon dioxide uptakes gets reduced thus lower plant growth. However, the root of the plant would pull in more nutrients and there are more forces acting on the plant - from the leaves to the roots - and the plant experiences more stress (Grossiord et al., 2020).

Using organic fertilizer like the Japanese snail, would greatly help to lessen the cases of snail infestation and most importantly, sustainable agriculture would flourish probably resulting to improved corn production.

\section{Material and Methods}

\section{Collection, preparation and fermentation of organic fertilizer}

Raw materials used in this study were seaweed, bamboo shoot (Bambusa vulgaris), Japanese snail (Achatina fulica) and Guduchi (Tinospora cordifolia). These were all collected at Cebu Technological University-Barili Campus farm vicinity. The shoots were washed, then chopped or crushed in the case of Japanese snail into small pieces for effective fermentation. The samples were added with molasses with a ratio of 1:1 following Pascual et al. (2013). The study used $10 \mathrm{~kg}$ of every raw material and 10 liters of molasses, which was harvested after seven days of fermentation. The collected residue was safely kept in a storage container in a cool and dry place.

\section{Preparation of bamboo shoots fertilizer}

Preparation of bamboo shoot fertilizer differed from the other organic fertilizers used in this study. After it was washed three times and chopped into smaller pieces, it was added with water with the same ratio of $1: 1$. This was then harvested after 24 hours and the collected residue was then kept in clean container in a cool and dry place until further use.

\section{Experimental site and plant sampling}

The experiment was conducted inside the Nursery Area of Cebu Technological University, Barili Campus $\left(10^{\circ} 7^{\prime} 53^{\prime \prime} \mathrm{N}, 123^{\circ} 32^{\prime} 45^{\prime \prime} \mathrm{E}\right)$ with an area of $8.95 \mathrm{~m} \mathrm{x} 6$ $\mathrm{m}$. The pots (dimension of pot) were filled with $2.5 \mathrm{~kg}$ of garden soil. Three seeds of Corn were planted in each pot and a week after emergence, plants were thinned to one per pot.

\section{Experimental design and treatments}

The experiment was laid out in Randomized Complete Block Design with seven treatments; commercial compost, seaweed residue, bamboo shoot residue, Japanese snail residue, combination of seaweed sludge and plant pesticide residue, combination of bamboo 
shoot residue and plant pesticide residue and lastly the combination of Japanese snail residue and plant pesticide residue applied basally at $10 \mathrm{t} / \mathrm{ha}$. Each treatment was replicated three times.

\section{Treatment}

T0 Commercial Compost Fertilizer

T1 Seaweed Residue (SR)

T2 Bamboo Shoot Residue (BSR)

T3 Japanese Snail Residue (JSR)

T4 1/2 Seaweed Sludge + 1/2 Plant Pesticide Residue (Guduchi)

T5 1/2 Bamboo Shoot Residue + 1/2 Plant Pesticide Residue (Guduchi)

T6 1/2 Japanese Snail Residue $+1 / 2$ Plant Pesticide Residue (Guduchi)

\section{Data collection}

The data of following parameters were collected in this study: plant height $(\mathrm{cm})$ - measured using a ruler for five weeks with a one-week interval after planting; leaf length - measured using a ruler from the tip of the longest leaf at one end of the leaf to the other end; number of leaves - counted every week in the whole plant; photosynthesis response - this was measured using LI-6800 Portable Photosynthesis System (LiCor, Inc., Lincoln, NE, USA) with 7-day interval; weight of ears and weight of kernels/ear - measured using a digital weighing balance; computed yield in t/ha - calculated by getting the moisture content of the crop multiplied by the average number of crop planted per hectare and divided by 10,000 .

\section{Statistical analysis}

The data was subjected to analysis of variance (ANOVA) and further test was done using tukey's test at $\mathrm{p}<0.05$ to test for differences between treatment means.

\section{Results and Discussion}

\section{Morphological responses (vegetative)}

Table 1 (below) clearly indicates that Japanese snail fertilizer produced the tallest plants for almost every week except the first and third week. The tallest height of the Japanese snail fertilized plant was at $156.80 \pm 6.16 \mathrm{SD} \mathrm{cm}$ and the lowest was the combination of seaweed fertilizer and the organic pesticide at
$115.73 \pm 7.52 \mathrm{SD} \mathrm{cm}$, this makes Japanese snail fertilizer $26 \%$ taller. Leaf length has the same result which the Japanese snail fertilization outperformed all other fertilizer for the whole duration of the study, except on the first and fifth week where there was no significant difference among fertilizers used. Plants fertilized with Japanese snail produced $75.07 \pm 4.55 \mathrm{SD} \mathrm{cm}$ leaf length. This result corresponds with the study of Carabio et al. (2021), where lettuce produced the highest plant height after application of fermented Japanese fertilizer.

In the study of Akinnusi et al. (2018), it was found out that there is a higher concentration of calcium in the Achatina fulica snail and was confirmed that $\mathrm{CaCO} 3$ is the main component or element. There was also a high amount of phosphorus that was reported which is a vital component of the biosphere as it is involved in basic metabolic process of energy transfer. The high phosphorus concentration in the shell might be due to its inclusion in conchiolin, a major component of mollusk shells as well as the presence of $\mathrm{CaPO} 4$ in the snail shell. Calcium is required for cell elongation in both shoots and roots (Burstrom, 2008). Furthermore, it was supported by the study of Upadhyaya et al. (2017) where the shoot length has also increased with increase in the concentration of calcium phosphate up to $20 \mathrm{mg} / \mathrm{L}$ by $5 \%$ relative to the control. In leaf length, this has the same result with Hagagg et al. (2019) that trees sprayed with kaolin and calcium carbonate produced the largest leaf area, while untreated trees produced significantly the smallest leaf area in both seasons.

\section{Morphological responses (reproductive)}

In this figure, it can be seen that in the weight of ears, Japanese snail fertilizer produced the highest at 86.6 \pm

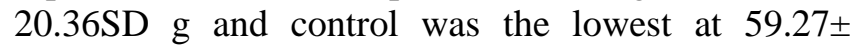
12.70SD g. However, in the weight of kernels per ear, seaweed basal fertilizer produced the highest but is comparable with Japanese snail fertilizer at $70.14 \pm$ 16.03SD $g$ and $69.60 \pm 1.48 \mathrm{SD} g$, respectively. It was

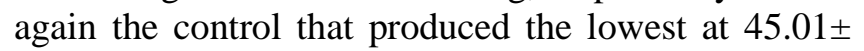
$12.82 \mathrm{SD}$ g. This result was just the same in the vegetative growth where Japanese snail fertilizer showed the most effective response on native corn through its nutrient composition like phosphorus and calcium. The result was supported by the study of Amanullah et al. (2009) where it was reported that application of different phosphorus sources can increase grains ear ${ }^{-1}$ and grains weight in maize crop. 
Nonna Fatima H. Abello et al

Table-1. Effects of five organic fertilizer treatments on plant vegetative growth

\begin{tabular}{|c|c|c|c|c|c|c|c|c|}
\hline \multicolumn{7}{|c|}{ Plant Height \pm SD cm) } \\
\hline Treatment & Week 1 & Week 2 & Week 3 & Week 4 & Week 5 & Week 6 & Week 7 & Week 8 \\
\hline T0 & $18.95 \pm 2.58$ & $30.10 \pm 2.84 \mathrm{ab}$ & $46.10 \pm 8.31 \mathrm{abc}$ & $68.07 \pm 13.38 \mathrm{ab}$ & $92.10 \pm 24.43 \mathrm{ab}$ & $111.73 \pm 31.51 \mathrm{bc}$ & $125.47 \pm 28.24 \mathrm{ab}$ & $128.93 \pm 38.25 \mathrm{bc}$ \\
\hline T1 & $18.99 \pm 2.60$ & $25.16 \pm 0.59 \mathrm{a}$ & $43.30 \pm 7.26 \mathrm{abc}$ & $73.53 \pm 16.08 \mathrm{~b}$ & $97.40 \pm 23.66 \mathrm{ab}$ & $122.40 \pm 30.51 \mathrm{c}$ & $125.00 \pm 28.79 \mathrm{ab}$ & $129.13 \pm 22.96 \mathrm{bc}$ \\
\hline T2 & $18.03 \pm 0.85$ & $29.80 \pm 0.79 \mathrm{ab}$ & $52.80 \pm 3.93 \mathrm{c}$ & $71.60 \pm 9.18 \mathrm{ab}$ & $98.77 \pm 13.9 \mathrm{ab}$ & $117.47 \pm 18.60 \mathrm{c}$ & $138.27 \pm 7.77 \mathrm{c}$ & $139.13 \pm 6.28 \mathrm{c}$ \\
\hline T3 & $18.71 \pm 0.84$ & $30.63 \pm 2.18 \mathrm{~b}$ & $34.80 \pm 2.50 \mathrm{a}$ & $89.27 \pm 10.06 \mathrm{c}$ & $114.00 \pm 15.98 \mathrm{~b}$ & $144.87 \pm 15.47 \mathrm{~d}$ & $156.00 \pm 16.11 \mathrm{~d}$ & $156.80 \pm 6.16 \mathrm{~d}$ \\
\hline T4 & $16.16 \pm 5.96$ & $27.56 \pm 0.87 \mathrm{ab}$ & $37.87 \pm 3.75 \mathrm{ab}$ & $56.27 \pm 12.40 \mathrm{a}$ & $78.40 \pm 14.8 \mathrm{a}$ & $92.60 \pm 24.12 \mathrm{a}$ & $107.73 \pm 7.52 \mathrm{a}$ & $115.07 \pm 9.63 \mathrm{a}$ \\
\hline T5 & $19.24 \pm 1.82$ & $29.44 \pm 2.71 \mathrm{ab}$ & $44.10 \pm 3.08 \mathrm{abc}$ & $69.27 \pm 7.11 \mathrm{ab}$ & $90.83 \pm 14.68 \mathrm{a}$ & $104.33 \pm 13.26 \mathrm{~b}$ & $121.33 \pm 5.96 \mathrm{a}$ & $121.20 \pm 9.2 \mathrm{~b}$ \\
\hline T6 & $18.88 \pm 3.67$ & $30.82 \pm 5.85 \mathrm{~b}$ & $47.29 \pm 39.62 \mathrm{bc}$ & $73.53 \pm 11.66 \mathrm{~b}$ & $91.60 \pm 18.22 \mathrm{a}$ & $115.00 \pm 24.20 \mathrm{bc}$ & $130.133 \pm 34.17 \mathrm{bc}$ & $133.47 \pm 35.32 \mathrm{bc}$ \\
\hline & & & & Leaf Length \pm SD cm) & & 63.15 \\
\hline T0 & $19.55 \pm 0.80$ & $33.95 \pm 8.33 \mathrm{ab}$ & $51.92 \pm 8.30 \mathrm{ab}$ & $58.02 \pm 8.94 \mathrm{ab}$ & $61.00 \pm 16.30 \mathrm{a}$ & $63.03 \pm 9.65 \mathrm{ab}$ & $63.59 \pm 10.69$ & $65.87 \pm 14.29 \mathrm{a}$ \\
\hline T1 & $18.54 \pm 3.50$ & $32.21 \pm 3.91 \mathrm{ab}$ & $50.19 \pm 9.32 \mathrm{ab}$ & $56.14 \pm 6.28 \mathrm{ab}$ & $63.13 \pm 6.92 \mathrm{ab}$ & $64.73 \pm 9.35 \mathrm{abc}$ & $66.15 \pm 7.92$ & $69.13 \pm 3.25 \mathrm{ab}$ \\
\hline T2 & $20.03 \pm 1.41$ & $32.97 \pm 1.53 \mathrm{ab}$ & $53.07 \pm 6.32 \mathrm{ab}$ & $61.40 \pm 18.72 \mathrm{~b}$ & $64.47 \pm 3.33 \mathrm{ab}$ & $68.93 \pm 5.60 \mathrm{bc}$ & $68.71 \pm 6.13$ & $71.47 \pm 6.46 \mathrm{ab}$ \\
\hline T3 & $22.06 \pm 2.04$ & $37.23 \pm 5.89 \mathrm{~b}$ & $57.46 \pm 4.58 \mathrm{~b}$ & $67.85 \pm 5.77 \mathrm{~b}$ & $73.40 \pm 4.02 \mathrm{~b}$ & $74.07 \pm 4.55 \mathrm{c}$ & $74.21 \pm 2.59$ & $75.73 \pm 3.77 \mathrm{~b}$ \\
\hline T4 & $17.9 \pm 0.58$ & $31.09 \pm 1.55 \mathrm{a}$ & $43.29 \pm 4.58 \mathrm{a}$ & $47.63 \pm 8.71 \mathrm{a}$ & $54.07 \pm 13.29 \mathrm{a}$ & $57.27 \pm 6.52 \mathrm{a}$ & $62.28 \pm 3.91$ & $67.33 \pm 4.03 \mathrm{a}$ \\
\hline T5 & $19.95 \pm 1.76$ & $32.21 \pm 2.04 \mathrm{ab}$ & $45.63 \pm 55.48 \mathrm{a}$ & $54.13 \pm 6.42 \mathrm{ab}$ & $55.80 \pm 3.14 \mathrm{a}$ & $63.13 \pm 5.33 \mathrm{ab}$ & $64.87 \pm 4.99$ & $66.33 \pm 3.14 \mathrm{a}$ \\
\hline T6 & $19.76 \pm 2.70$ & $34.55 \pm 6.05 \mathrm{ab}$ & $50.53 \pm 9.61 \mathrm{ab}$ & $56.50 \pm 6.65 \mathrm{ab}$ & $59.67 \pm 10.76 \mathrm{a}$ & $60.79 \pm 12.15 \mathrm{ab}$ & $69.49 \pm 3.07$ & $69.20 \pm 9.46 \mathrm{ab}$ \\
\hline
\end{tabular}

The probable reason could be that at high utilization of nitrophosphorus, favorable environment, higher assimilates production and its conversion to starches resulted higher grains number. In case of interaction might be due to the genetic potential of these varieties to utilize phosphorus sources nutrients to increase grain ear (Azeem et al., 2018).

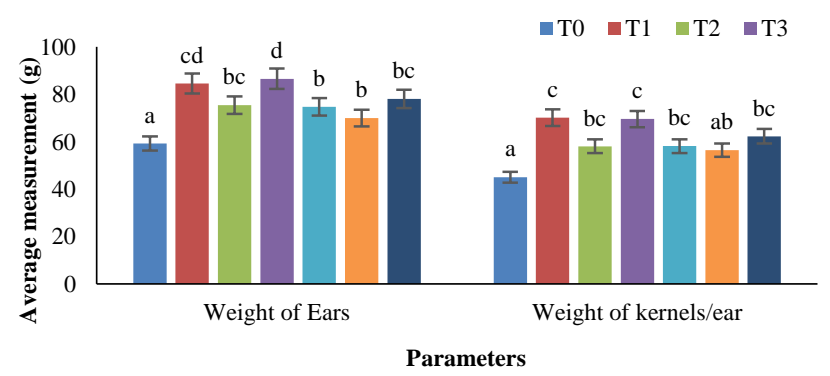

Figure-1.Reproductive growth of native corn after application of basal organic fertilizer. Different small superscript letters indicate significant differences, determined by tukey's test at $\mathbf{p}=\mathbf{0 . 0 5}$

It can be seen in this figure, that Japanese snail fertilizer produced the lowest computed yield of all the treatments used at $2.13 \pm 09 \mathrm{SD}$ g. The reason behind this is that the other treatments have higher moisture content thus, higher overall computed yield. However, it can also be observed that the combination of Japanese snail fertilizer and pesticide showed the highest computed yield at $3.33 \pm 04 \mathrm{SD} g$ (Figure 1). The indication of both results involving Japanese snail fertilizer is both beneficial to native corn. If the case was for seed preservation, Japanese fertilizer alone would be suitable for having the very low moisture content.

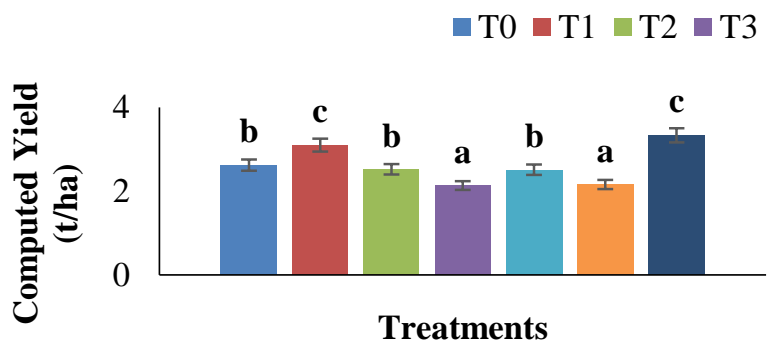

Figure-2. Computed yield of native corn after application of basal organic fertilizer at $\mathrm{MC}=18$. Different small superscript letters indicate significant differences, determined by tukey's test at $\mathbf{p}=\mathbf{0 . 0 5}$

In the study of McCormack (2004), low seed moisture content is a pre-requisite for long-term storage, and is the most important factor affecting longevity. Seeds lose viability and vigor during processing and storage mainly because of high seed moisture content. As reported by Kim (2018), seed moisture is the most 
important factor in maintaining seed viability during storage, as it is the primary factor controlling all cellular activities. On the other hand, when focusing on yield alone, the combination of Japanese snail and pesticide is recommended. Higher computed yield means higher income to farmers.

It was reported by Chaudhary et al. (2014) that guduchi, the pesticide used in this study is rich in protein (11.2\%), calcium and phosphorus. This was just like in Japanese snail where it was found out to have higher amount of calcium carbonate and phosphorus in the shell (Akinnusi et al., 2018). Taliman et al. (2019), found out that seed yield was higher in the higher level of $\mathrm{P}$ application for all Soybean Low-Phytate lines in which treatment of Japanese snail fertilizer and pesticide in this study is abundant. This was supported in the study of Zhu et al. (2012), where an increase of $\mathrm{P}$ fertilizer, grain yield was significantly increased, but a gradual decrease in grain yield was detected after it reached the maximum.

\section{Physiological responses}

Based on the result (Figure 1), plants applied with the combination of fermented seaweed and organic pesticide and japanese snail and organic pesticide had the highest transpiration rate in the 2 nd month of the study at $1604174591.67 \pm 192.14 \mathrm{SD} \mu \mathrm{mol} \mathrm{H} 2 \mathrm{O} \mathrm{m}-2 \mathrm{~s}-$ 1 and $1604175187.0000 \pm 220.85 \mathrm{SD} \mu \mathrm{mol} \mathrm{H} 2 \mathrm{O} \mathrm{m}-2 \mathrm{~s}-$ 1, respectively (Figure 1A). This was supported by AlGhamdi and Elansary (2018) which reported a significant increase of the total transpiration rate and stomatal conductance of asparagus plants when treated by a $7 \mathrm{~mL} . \mathrm{L}-1$ Ascophyllum nodosum seaweed extract in comparison to the untreated plants. There was no existing transpiration rate data that was affected by Japanese snail fertilizer on plants. Transpiration in the stoma only occurs due to the necessity of the plant to obtain carbon from their environment to allow photosynthesis. The carbon is in the gas phase in the atmosphere as $\mathrm{CO} 2$. In this process, some water vapor escapes by transpiring enormous amounts of water, and the plant is at risk of dehydrating and even death.

Vapor Pressure Deficit at Leaf Temperature showed the highest amount at the combination of Seaweed fertilizer and organic pesticide and the lowest in Japanese snail treatment plants at $4.83 \pm 0.04 \mathrm{SD} \mathrm{kPa}$ and $4.54 \pm 0.02 \mathrm{SD} \mathrm{kPa}$, respectively for the first month (Figure 1B). It can be seen that treatments of combined seaweed fertilizer and pesticide and also in Japanese alone have the lowest and highest plant height at fourth week at $56.27 \pm 12.40 \mathrm{SD} \mathrm{kPa}$ and $89.27 \pm 10.06 \mathrm{SD} \mathrm{kPa}$, respectively. Vapor pressure deficit at leaf temperature strongly affects photosynthetic rates. Stomatal closure restricts not only the diffusion of water out of the leaf but also carbon dioxide diffusion into the leaf, resulting in reduced photosynthesis (Grossiord et al., 2020). Plants respond differently to VPD depending on the environment in which they have adapted but, in this case, applied basal fertilizers are a big factor for a significant difference of VPD despite of the same environment of all of the plant samples. Hence in this study, higher VPD like in the combined seaweed fertilizer and organic pesticide have a lower plant height compared to the other treatments.

This study resulted to a highest assimilation rate at the combined seaweed fertilizer on the first month. The combined seaweed fertilizer and organic pesticide has the lowest plant height in which it is the same treatment that has the highest assimilation rate at $12.12 \pm 0.65 \mathrm{SD}$ $\mathrm{s}$ (Figure 1C). Photosynthesis results from the assimilation of water and carbon dioxide, whereby they are absorbed by the plant and consequently converted into a plethora of organic molecules directly in the plant's numerous cells. A reduced assimilation rate meant that $\mathrm{CO} 2$ and water are less utilized for the production of essential biomolecules which would result to lower growth rate of the plant (Lawlor and Cornic, 2002). This explains physiologically and morphologically the results of this study.

Stomatal conductance to $\mathrm{CO} 2$ (Figure 1D) and total conductance to $\mathrm{CO} 2$ (Figure 1E) followed similar trend in which the combined Japanese snail and organic pesticide treated plants has the highest amount at $478.64 \pm 34.83 \mathrm{SD} \mu \mathrm{mol} \mathrm{mol}{ }^{-}$and $47.51 \pm 3.55 \mathrm{SD} \mu \mathrm{mol}$ $\mathrm{mol}^{-}$, respectively. Stomatal conductance directly modifies plant-water relations and photosynthesis. Stomatal conductance varies with changes in environmental and plant conditions such as temperature and vapor pressure deficit (VPD) (Urban et al., 2017). Increased total conductance to CO2 can also be an underlying cause for increased stomatal conductance, or stomatal conductance may have caused an increase in the gas exchange rate, which is why the two would always have the same trend.

The graph (Figure 2) clearly indicates that vapor pressure deficit at leaf temperature has a strong relationship with plant height on the plants applied with Japanese snail fertilizer on the first month at $\mathrm{R}=$ 0.7538. This also showed significantly strong relationship with the reproductive growth of native corn on weight of ears and on weight of kernels per ear at $\mathrm{R}=-0.868$ and $\mathrm{R}=-0.861$, respectively. 
A

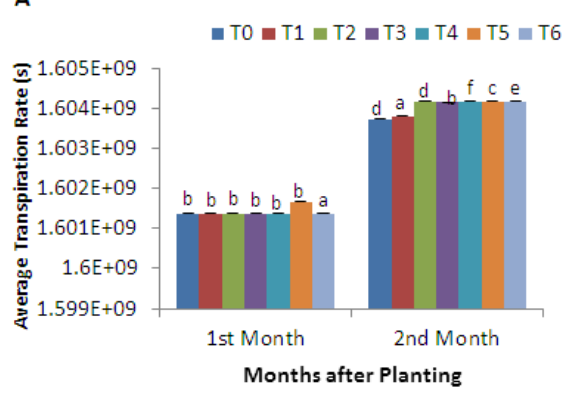

B

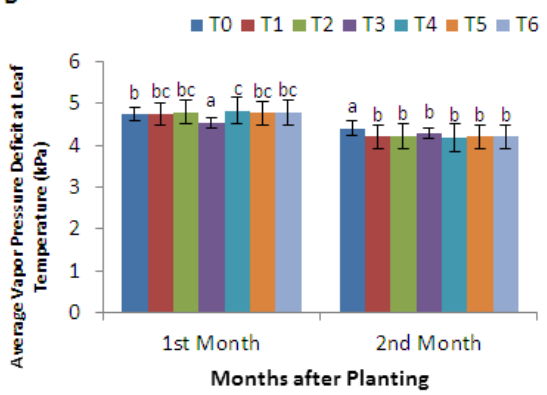

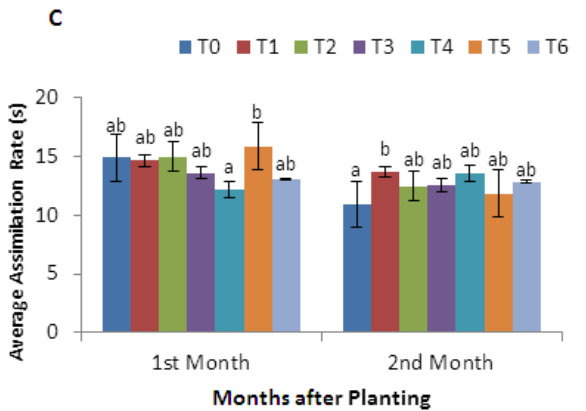
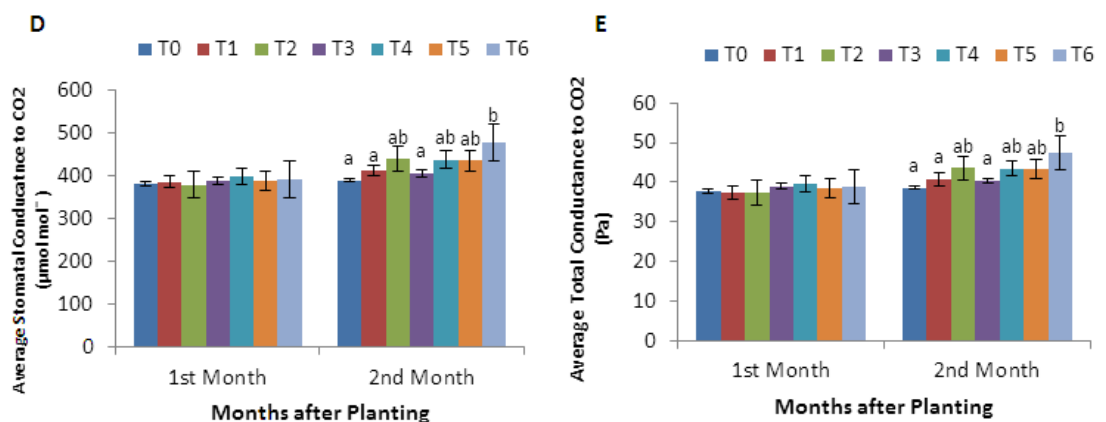

Figure-3. Photosynthetic Responses after application of different treatments on Corn: (A) Average Transpiration Rate (B) Average vapor pressure deficit at lead temperature (C) Average Assimilation Rate (D) Average Stomatal Conductance to $\mathrm{CO}_{2}(\mathrm{E})$ Average Total Conductance to $\mathrm{CO}_{2}$

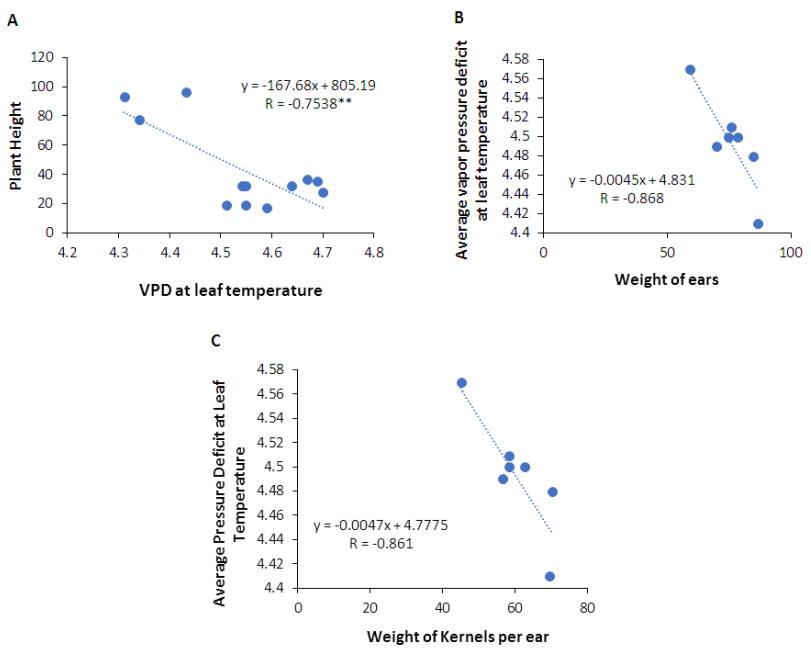

Figure-4. Relationship of VPD deficit at leaf temperature after the application of Japanese Snail Fertilizer; (A) plant height, (B) weight of ears and (C) weight of kernels per ear

This just proved that VPD indeed is a good indicator for growth of the native corn where reduced VPD at leaf temperature has increased plant height on the first month. It was also stated in the study of Jiao et al. (2019), that reducing the VPD alleviated the water stress of the plant which cause an increase in gas exchange area of the leaf, and was beneficial to the entry of $\mathrm{CO} 2$ into the leaf. The increase of $\mathrm{CO} 2$ was more beneficial to promote the photosynthetic rate and then improve the water use efficiency and yield in Tomato. This was also supported by the study of Lorenzo et al. (2003), where shoot growth of Tomato was also negatively affected by high VPD regime in High $(\mathrm{H})$ 2.5-4 kPa treatment.

\section{Conclusion}

The use of Japanese snail basal fertilizer improves indigenous corn performance both morphologically and physiologically. This showed promising results in enhancing plant growth of indigenous corn by reducing VPD at leaf temperature which can be used easily by the farmers.

\section{Acknowledgement}

The authors wish to acknowledge the support provided by Cebu Technological University for the realization of this study. 
Disclaimer: None.

Conflict of Interest: None.

Source of Funding: This study was financially supported by Cebu Technological University, Philippines under General Appropriations Act.

\section{References}

Akinnusi FAO, Oni OO and Ademolu KO, 2018. Mineral composition of giant African land snail's (Archachatina marginata) shells from six south West States, Nigeria. Nigerian J. Anim. Sci. 20(4): 485-489.

Al-Ghamdi AA and Elansary HO, 2018. Synergetic effects of 5-aminolevulinic acid and Ascophyllum nodosum seaweed extracts on Asparagus phenolics and stress related genes under saline irrigation. Plant Physiol. Biochem. 129: 273-284.

Amanullah J, Khattak R and Khalil S, 2009. Plant Density and Nitrogen Effects on Maize Phenology and Grain Yield. Journal of Plant Nutrition. 32: 246-260.

Amper ZHS, Eugenio AR, Bacon PM and Bonita B 2018. Subsistence oriented corn production in Cebu: contrasting local knowledge and development perspectives. Aghamtao J. 26: 75-93.

Azeem K, Khan A, Naz F, Ilyas M, Azeem I, Anwar F and Ahmad W, 2018. The Impact of Different P Fertilizer Sources on Growth, Yield and Yield Component of Maize Varieties. Agric. Res. Technol: Open Access J. 13(3): 55-58.

BAS (Bureau of Agricultural Statistics), 2012. www.countrystat.bas.gov.ph. Date Accessed: December 7, 2020.

Burstrom H, 2008. Calcium and plant growth. Biol. Rev. 43: 287.

Carabio DE, Pascual VU, Abello NFH, Rondina ME and Pascual PRL, 2021. Combined Application of Fermented Bamboo (Bambusa spinosa) And Mollusk (Achatina fulica) Liquid Fertilizer Can Improved Lettuce (Lactuca Sativa Var. Curly Green) Production. Plant Cell Biotechnol. Mol. Biol. 22(3-4): 56-64.

Chaudhary N, Siddiqui MB and Khatoon S, 2014. Pharmacognostical evaluation of Tinospora cordifolia (Willd) Meirs and identification of biomarkers. J. Res. Indian Med. 13: 543-550.

Grossiord C, Bucklez T, Cernusak L, Novick K, Poulter B, Siegwolf R, Sperry J and McDowell N, 2020. Plant responses to rising vapor pressure deficit. New Phytologist. 226 (6): 1550-1566.
Hagagg L, Abd-Alhamid N and Maklad M, 2019. Effect of kaolin and calcium carbonate on vegetative growth, leaf pigments and mineral content of kalamata and manzanillo olive trees. Middle East J. Agric. Res. 8: 298-310.

Huma B, Hussain M, Ning C and Yuesuo Y, 2019. Human Benefits from Maize. Sch. J. Appl. Sci. Res. 2 (2): 4-7.

Jatto E, Imohimi A and Medjor W, 2010. Proximate and Mineral Composition of Different Species of Snail Shell. PJTS. 11(1): 416-419.

Jiao XC, Song XM, Zhang DL, Du QJ and Li JM, 2019. Coordination between vapor pressure deficit and $\mathrm{CO} 2$ on the regulation of photosynthesis and productivity in greenhouse tomato production. Sci. Rep. 9: 8700.

Kim DH, 2018. Extending Populus seed longevity by controlling seed moisture content and temperature. PloS one. 13(8): e0203080.

Lawlor DW and Cornic G, 2002. Photosynthetic carbon assimilation and associated metabolism in relation to water deficits in higher plants. Plant Cell Environ. 25(2): 275-294.

Lesik MM, Dadi O, Wahida AG and Laban S, 2019. Nutrient analysis of liquid organic fertilizer from agricultural waste and rumen liquid. IOP Conf. Series: Earth Environ. Sci. 343: 012178.

Lorenzo P, Sánchez-Guerrero MP and Medrano E, 2003. Effect of Vapour Pressure Deficit On Growth, Development And Dry Matter Allocation Of Tomato Plants. Acta Hortic. 614: 863-867.

McCormack J, 2004. Seed Processing and Storage: Principles and practices of seed harvesting, processing, and storage: an organic seed production manual for seed growers in the MidAtlantic and Southern U.S. USDA SARE grant. Available for free download at: www.savingourseeds.org. Date Accessed: January 2021

Pascual PRL, Jarwar A and Nitural PS, 2013. Fertilizer, fermented activators, and EM utilization in pechay (Brassica pekinensis L.) production. Pak. J. Agric Agric. Engg. Vet. Sci. 29(1): 56-69.

Pascual PRL, Carabio DE, Rondina ME, Abello NFH and Pascual VU, 2020. Fermented Seaweed (Kappaphycus Alverezii) By-Product Promotes Growth and Development of Lettuce (Lactuca Sativa Var. Curly Green). Plant Cell Biotechnol. Mol. Biol. 21(71-72): 208-214.

Sreenivasa BT, Divya SH, Kumar JBN and Sivaprasad, V, 2016. Laboratory evaluation ofchemicals 
against Giant African Snail, Achatina fulica bowdich and bio-assay studies on silkworm,Bombyxmori (L.). Biolife. 4(2): 289294.

Taliman N, Dong Q, Echigo K, Raboy V and Saneoka H, 2019. Effect of Phosphorus Fertilization on the Growth, Photosynthesis, Nitrogen Fixation, Mineral Accumulation, Seed Yield, and Seed Quality of a Soybean Low-Phytate Line. Plants. 8(5):119.

Upadhyaya H, Begum L, Dey B, Nath PK and Panda SK, 2017. Impact of Calcium Phosphate Nanoparticles on Rice Plant. J. Plant Sci. Phytopathol. 1: 1-10.

Urban J, Ingwers M, McGuire MA and Teskey R, 2017. Stomatal Conductance Increases with Rising Temperature. Plant Signal. Behav. 12(8): e1356534. doi: 10.1080/15592324.2017.1356534

Wang J, Lu X, Zhang J, Wei G and Xiong Y, 2020. Using golden apple snail to mitigate its invasion and improve soil quality: a biocontrol approach.
Environ. Sci. Pollut. Res. 27: 14903-14914.

Zhu X, LI C, Jiang Z, Huang L, Feng C, Guo W and Peng Y, 2012. Responses of Phosphorus Use Efficiency, Grain Yield, and Quality to Phosphorus Application Amount of Weak-Gluten Wheat. J. Integr. Agric. 11: 1103-1110.

\section{Contribution of Authors}

Abello NFH: Planned the study, collected and analyzed data and wrote manuscript

Remedios EA: Prepared materials, conducted study and collected data

Carabio DE: Literature Review, designed research methodology and data interpretation

Pascual VU: Manuscript critiquing, final reading and approval

Pascual PRL: Conceived idea, designed research methodology and analysed data 